\title{
Vibrio shiloi sp. nov., the causative agent of bleaching of the coral Oculina patagonica
}

1,2 Departments of
Molecular Microbiology
and Biotechnology ${ }^{1}$ and
Zoology ${ }^{2}$, George S. Wise
Faculty of Life Sciences,
Tel Aviv University, Ramat
Aviv, Israel 69978
3 DSMZ, Mascheroder Weg
1b, D-38124
Braunschweig, Germany

\author{
A. Kushmaro, ${ }^{1}$ E. Banin, ${ }^{1}$ Y. Loya, ${ }^{2}$ E. Stackebrandt ${ }^{3}$ and E. Rosenberg ${ }^{1}$ \\ Author for correspondence: E. Rosenberg. Tel: +972 36409838 . Fax: +972 36429377. \\ e-mail: eueqene@ccsg.tau.ac.il
}

\begin{abstract}
The aetiological agent of bleaching of the coral Oculina patagonica was characterized as a new Vibrio species on the basis of 16S rDNA sequence, DNA-DNA hybridization data and phenotypic properties, including the cellular fatty acid profile. Based on its 16S rDNA and DNA-DNA hybridization, the new Vibrio species is closely related to Vibrio mediterranei. The name Vibrio shiloi sp. nov. is proposed for the new coral-bleaching species, the type strain being $\operatorname{AK1}^{\top}\left(=\right.$ ATCC BAA-91 $^{\top}=$ DSM 13774 ${ }^{\top}$ ).
\end{abstract}

Keywords: coral bleaching, Vibrio, Vibrio shiloi

\section{INTRODUCTION}

Coral bleaching is the disruption of symbioses between coral hosts and photosynthetic microalgal endosymbionts, referred to as zooxanthellae (Brown et al., 1995). The loss of the pigmented zooxanthellae causes the coral to lose colour (bleaching) and eventually die, since a major portion of the coral's nutrition comes from the photosynthetic products of the algae. Coralbleaching events of unprecedented frequency and global extent were reported in the 1980s and 1990s (Glynn, 1991a, b; Goreau, 1990, 1994; HoeghGuldberg, 1999). Coral bleaching may be induced by a variety of environmental stimuli, including increased seawater temperature (Jokiel \& Coles, 1990). There has been speculation that large-scale bleaching episodes are linked to global warming (HoeghGuldberg, 1999).

Recently, we reported that bleaching of the coral Oculina patagonica, present in the Mediterranean Sea, is the result of a bacterial infection (Kushmaro et al., 1996, 1997). The causative agent, referred to as Vibrio sp. AK1, was present in all bleached $O$. patagonica and absent from all healthy (unbleached) corals examined. Pure cultures of $A K 1^{\mathrm{T}}$ caused bleaching when inoculated onto unbleached corals in controlled aquarium experiments. The first step in the infection process is the adhesion of cells of $A K 1^{\mathrm{T}}$ to the coral through a $\beta$-D-galactopyranoside receptor (Toren et al., 1998). Interestingly, the binding occurs only when the bacteria are grown at elevated seawater temperatures, which may explain how increased temperature causes

The GenBank/EMBL accession number for the 16S rDNA sequence of Vibrio shiloi $A K 1^{\top}$ is AF007115. coral bleaching (Kushmaro et al., 1998). Following adhesion, $A K 1^{\mathrm{T}}$ penetrates into the coral tissue, multiplies intracellularly (Banin et al., 2000) and produces toxins that inhibit photosynthesis and bleach and lyse the intracellular zooxanthellae (Ben-Haim et al., 1999). Although members of the genus Vibrio are common pathogens in the marine environment, $\mathrm{AK} 1^{\mathrm{T}}$ is the first vibrio that attacks zooxanthellae and has been proven to be responsible for the coral-bleaching disease. The present study was carried out in order to characterize the coral-bleaching pathogen further. The data suggest that strain $\mathrm{AK} 1^{\mathrm{T}}$ is a new marine species, for which the name Vibrio shiloi sp. nov. is proposed.

\section{METHODS}

Micro-organisms, media and growth conditions. $V$. shiloi $\mathrm{AK} 1^{\mathrm{T}}$ (= DSM $13774^{\mathrm{T}}$ ) was isolated from a bleached coral sample, as described previously (Kushmaro et al., 1996, 1997). Using the same techniques, an additional isolate ( $V$. shiloi AK2) was obtained from bleached corals at a different site in the Mediterranean Sea, off the coast of Israel. For comparative studies, Vibrio mediterranei ATCC $43341^{\mathrm{T}}$ (Pujalte \& Garay, 1986) was used. The Vibrio strains were routinely cultivated in $\mathrm{MB}$ medium $(0.9 \% \mathrm{NaCl}$ plus $1.8 \%$ Marine broth; Difco) or on MB agar (MB medium solidified with $1.8 \%$ Difco Bacto agar).

Phenotypic characterization. Biochemical tests were performed by using the API-20 NE system (micromethod tests for the identification of Gram-negative rods; bioMérieux). The standard API-20 NE method was used except that the media were adjusted to $3 \% \mathrm{NaCl}$. Growth and acid production from sucrose were measured on TCBS agar (Difco) after incubation at $30^{\circ} \mathrm{C}$ for $48 \mathrm{~h}$. Salt tolerance was determined in nutrient broth (Difco) containing varying concentrations of $\mathrm{NaCl}$. Sensitivity to the vibriostatic compound O129 (2,4-diamino-6,7-diisopropylpteridine; 
Sigma) was determined after incubation for $48 \mathrm{~h}$ at $30^{\circ} \mathrm{C}$ on $\mathrm{MB}$ agar containing $30 \mu \mathrm{g}$ of the compound on a disc.

Carbon utilization was analysed using BIOLOG GN microwell plates. Pure cultures were removed from MB plates and suspended in $20 \mathrm{ml}$ seawater and the density of the suspension was adjusted so that the $\mathrm{OD}_{590}$ was $0 \cdot 130-$ $0 \cdot 145$. The suspension was then distributed into BIOLOG GN microwell plates. Each plate contained 96 microwells with a different carbon source in each and tetrazolium violet as an indicator of metabolic activity. The plates were incubated for $48 \mathrm{~h}$ at $30^{\circ} \mathrm{C}$. Wells that changed to purple were marked as positive for metabolic activity.

The microbial fatty acid profile was analysed using the MIDI/Hewlett Packard microbial identification system (Analytical Services Inc.), which uses GC profiles of fatty acid methyl esters (Urdaci et al., 1990). Bacteria were grown on $\mathrm{MB}$ agar at $30^{\circ} \mathrm{C}$ for $48 \mathrm{~h}$.

For electron microscopy, exponentially growing bacteria in MB medium, as well as bacteria inside coral cells, were centrifuged and resuspended in seawater. The samples were adhered to a carbon-coated grid and stained with $1 \%$ uranyl acetate and photographed under a JEM-1200EX electron microscope (JEOL).

DNA isolation, amplification, sequencing and sequence analysis. Total DNA was extracted from $10 \mathrm{ml}$ bacterial cultures by using the SDS/proteinase/phenol/chloroform method described by Sambrook et al. (1989). 16S rDNA was amplified in a $50 \mu \mathrm{l}$ reaction consisting of $5 \mu \mathrm{l} 10 \times \mathrm{PCR}$ buffer, $1 \mu \mathrm{l} 2.5 \mathrm{mM}$ total dNTP mixture, $5 \mu \mathrm{M}$ of each primer, $10 \mathrm{ng}$ template DNA and 2.5 units Ex Taq DNA polymerase (Takara Shuzo). The primers used were 5'-GAGTTTGATCCTGGCTCAG-3' (positions 9-27, Escherichia coli numbering system) and 5'-AGAAAGGAGGTGATCCAGCC-3' (positions 1525-1544) (Rudner et al., 1998). Amplification conditions for the PCR (PTC-100; MJ Research Inc.) included an initial denaturation step at $95^{\circ} \mathrm{C}$ for $3 \mathrm{~min}$ followed by 30 cycles of $94^{\circ} \mathrm{C}$ for $1 \mathrm{~min}$, $55^{\circ} \mathrm{C}$ for $1 \mathrm{~min}$ and $72{ }^{\circ} \mathrm{C}$ for $1 \mathrm{~min}$ and a final extension step at $72{ }^{\circ} \mathrm{C}$ for $5 \mathrm{~min}$. Reaction products were checked for size and purity on $0.8 \%$ agarose gels and the DNA fragments were then recovered with a QIAquick gel extraction kit (Qiagen). DNA sequencing was performed using the chaintermination method in an ABI Prism (model 377, version 2.1.1) automatic sequencer. Primers used for the sequencing reaction were complementary to the conserved regions of the $16 \mathrm{~S}$ rDNA. The novel sequence of the $V$. shiloi AK $1^{\mathrm{T}} 16 \mathrm{~S}$ rDNA (1501 bp) was compared with homologous Vibrio 16S rDNA sequences taken from published databases (see Fig. 2). Calculation of similarity values and construction of the phylogenetic tree were performed as described by KitaTsukamoto et al. (1993).

DNA-DNA hybridization. DNA-DNA similarity experiments between $V$. shiloi $\mathrm{AK} 1^{\mathrm{T}}$ and $V$. mediterranei ATCC $43341^{\mathrm{T}}$ were carried out by the renaturation method (Escara \& Hutton, 1980; Huß et al., 1983), using DNA samples isolated by the method of Cashion et al. (1997). Reassociation was performed in $2 \times \mathrm{SSC}$ at $65^{\circ} \mathrm{C}$ (optimal conditions). Similarity values were calculated according to Jahnke (1992).

Cell fixation, antibodies and immunofluorescence microscopy. Overnight cultures of $V$. shiloi $\mathrm{AK} 1^{\mathrm{T}}$ and $V$. mediterranei ATCC $43341^{\mathrm{T}}$ grown in MB were fixed with $4 \%$ freshly prepared paraformaldehyde (final concentration) and incubated for $1-3 \mathrm{~h}$ at the growth temperature. The cells were washed five times in TBS (10 mM Tris base,
$150 \mathrm{mM} \mathrm{NaCl}$ ). Polyclonal antibodies were obtained from the serum of a rabbit, immunized with fixed $V$. shiloi cells. Fixed cells $\left(10^{6}\right.$ cells $\left.\mathrm{ml}^{-1}\right)$ were attached to microscope slides covered with poly-L-lysine $\left(50-100 \mu \mathrm{g} \mathrm{ml}^{-1}\right)$ and incubated for $2 \mathrm{~h}$ at room temperature. The slides were then washed once in TBS and incubated for $12 \mathrm{~h}$ at $4{ }^{\circ} \mathrm{C}$ with the polyclonal antibodies $(1: 1000$ dilution in TBS). The slides were washed five times in TBS and incubated with $5 \mu \mathrm{g}$ Rhodamine Red-X-conjugated anti-rabbit IgG $\mathrm{ml}^{-1}$ (Jackson ImmunoResearch). After incubation, the slides were washed five times in TBS and mounted with a solution of $90 \%$ glycerol containing $20 \mu \mathrm{g}$ 4,6-diamidino-2phenylindole (DAPI) $\mathrm{ml}^{-1}$ and $1 \mathrm{mg} p$-phenylenediamine $\mathrm{ml}^{-1}$. Coverslips were sealed and the slides were stored at $-30{ }^{\circ} \mathrm{C}$ until examination. The slides were examined using a Leica microscope (model DMRBE) with set filters A for DAPI and M2 filter for rhodamine.

\section{RESULTS}

Exponentially growing $V$. shiloi $\mathrm{AK}^{\mathrm{T}}$ is a Gramnegative, motile, rod-shaped bacterium $(2 \cdot 4 \times 1.6 \mu \mathrm{m})$ that has a single, polar, sheathed flagellum (Fig. 1a).
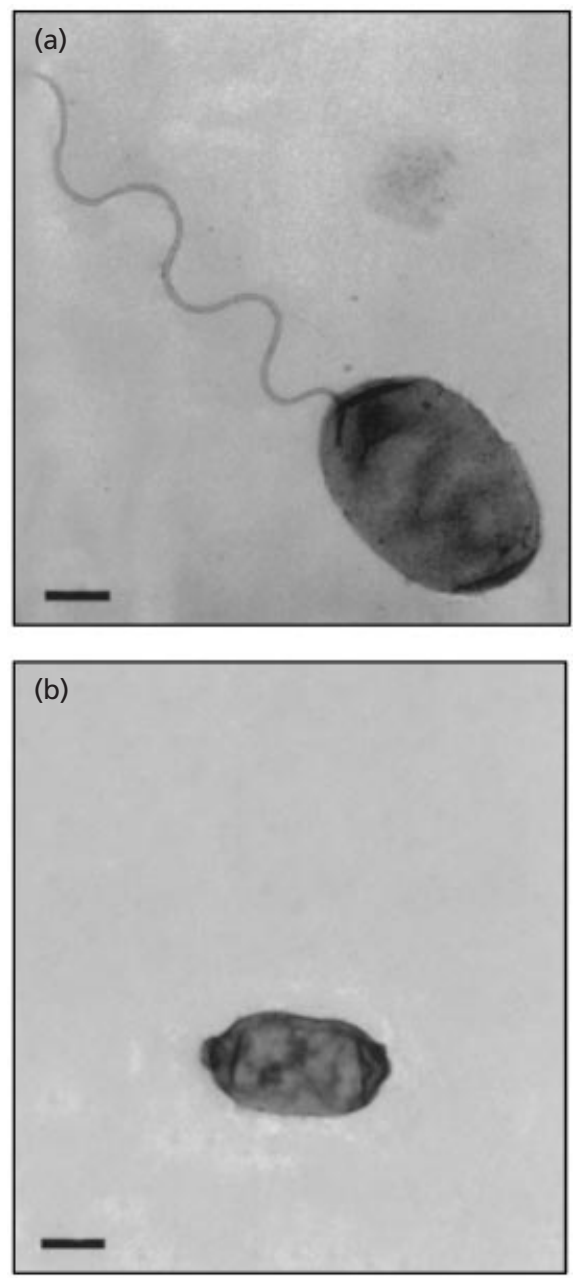

Fig. 1. Electron micrographs of negatively stained cells of $V$. shiloi $A K 1^{\top}$. (a) Exponentially growing cells. (b) Cells growing intracellularly. Bars, $0.5 \mu \mathrm{m}$. 


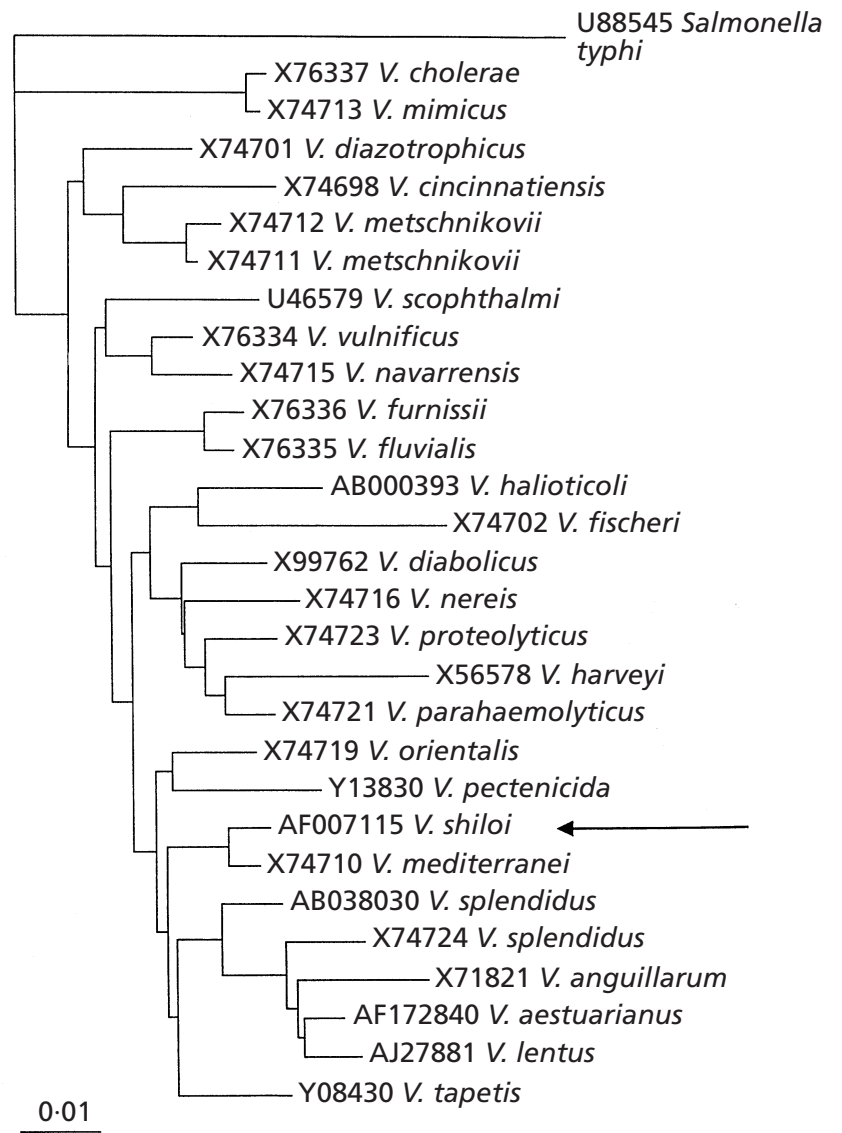

Fig. 2. Phylogenetic tree based on $16 \mathrm{~S}$ rDNA sequences, showing the relationships among 27 Vibrio reference strains in comparison to $V$. shiloi $A K 1^{\top}$ (arrow). Sequence accession numbers are given. Salmonella typhi was used as the outgroup.

When growing intracellularly in coral tissue, the cells lack the flagellum and are smaller $(2.0 \times 1 \cdot 0 \mu \mathrm{m}$; Fig. 1b). These properties, together with its ability to form yellow colonies on TCBS agar and its sensitivity to the vibriostatic agent $\mathrm{O} 129$, suggest that $\mathrm{AK} 1^{\mathrm{T}}$ is a species of the genus Vibrio (Farmer \& Hickman-Brenner, 1992). The sequence of the $16 \mathrm{~S}$ rDNA of strain AK $1^{\mathrm{T}}$ was determined and compared with data for known Vibrio species (Fig. 2). The sequence of strain $\mathrm{AK} 1^{\mathrm{T}}$ is related most closely to $V$. mediterranei, with 1425 of 1438 of the nucleotides being identical, 9 being different (including a nucleotide gap) and 4 undefined (in $V$. mediterranei). Assuming that the undefined residues are identical, the overall $16 \mathrm{~S}$ rDNA similarity is $99 \cdot 4 \%$. DNA-DNA hybridization results showed that strain $\mathrm{AK}^{\mathrm{T}}$ and $V$. mediterranei are $72 \%$ related at the total DNA level.

The cellular fatty acid composition of $V$. shiloi $\mathrm{AK} 1^{\mathrm{T}}$ is summarized in Table 1. Comparison of the fatty acid profile of strain $A K 1^{\mathrm{T}}$ with bacteria in the database also placed it clearly in the genus Vibrio. However, as seen in Table 1, the fatty acid composition of $V$. shilo $i$ $\mathrm{AK} 1^{\mathrm{T}}$ is very different from that of $V$. mediterranei.
Table 1. Fatty acid profiles of $V$. shiloi $A K 1^{\top}$ and $V$. mediterranei ATCC $43341^{\top}$

Values are percentages of the total fatty acid. Fatty acids are listed as follows: numbers before the colon indicate the number of carbon atoms and numbers after the colon refer to the number of double bonds; $3-\mathrm{OH}$ indicates a hydroxy group at carbon- $3 ; \omega 5 c, \omega 7 c, \omega 9 t$ etc. indicate the doublebond position from the hydrocarbon end of the carbon chain; $c$, cis isomer; $t$, trans isomer. ND, Not detected.

\begin{tabular}{|c|c|c|}
\hline Fatty acid & V. shiloi $\mathrm{AK}^{\mathrm{T}}$ & $\begin{array}{l}\text { V. mediterranei } \\
\text { ATCC } 43341^{\mathrm{T}}\end{array}$ \\
\hline $12: 0$ iso & $0 \cdot 1$ & ND \\
\hline $12: 0$ & $4 \cdot 7$ & $5 \cdot 0$ \\
\hline $13: 1$ iso & ND & $1 \cdot 1$ \\
\hline $13: 0$ iso & $0 \cdot 4$ & $2 \cdot 0$ \\
\hline $12: 0$ iso $3-\mathrm{OH}$ & $0 \cdot 1$ & ND \\
\hline $12: 03-\mathrm{OH}$ & $2 \cdot 0$ & $2 \cdot 2$ \\
\hline $14: 0$ iso & $4 \cdot 0$ & $1 \cdot 3$ \\
\hline $14: 1$ & ND & $1 \cdot 0$ \\
\hline $14: 0$ & $5 \cdot 9$ & $8 \cdot 0$ \\
\hline $15: 0$ iso & $0 \cdot 5$ & $2 \cdot 3$ \\
\hline $15: 0$ anteiso & $0 \cdot 5$ & ND \\
\hline $15: 1$ & ND & $2 \cdot 0$ \\
\hline $15: 0$ & $0 \cdot 4$ & $0 \cdot 3$ \\
\hline $14: 0$ iso $3-\mathrm{OH}$ & $1 \cdot 1$ & $\mathrm{ND}$ \\
\hline 14:0 3-OH & ND & $2 \cdot 6$ \\
\hline $16: 1$ iso or $14: 03-\mathrm{OH}$ & $3 \cdot 1$ & $\mathrm{ND}$ \\
\hline $16: 0$ & $10 \cdot 0$ & $2 \cdot 5$ \\
\hline $16: 1$ & ND & $30 \cdot 0$ \\
\hline $\begin{array}{l}16: 1 \omega 7 c \text { or } 15: 0 \\
\text { iso } 2-\mathrm{OH}\end{array}$ & $32 \cdot 5$ & ND \\
\hline $16: 1 \omega 5 c$ & $0 \cdot 1$ & ND \\
\hline $16: 0$ & $12 \cdot 1$ & $16 \cdot 0$ \\
\hline $17: 0$ iso & $0 \cdot 2$ & $1 \cdot 6$ \\
\hline $17: 0$ anteiso & $0 \cdot 3$ & ND \\
\hline $17: 1$ & ND & $2 \cdot 7$ \\
\hline $17: 1 \omega 8 c$ & $0 \cdot 6$ & ND \\
\hline $17: 0$ & $0 \cdot 2$ & $0 \cdot 3$ \\
\hline $18: 1$ iso $\mathrm{H}$ & $0 \cdot 5$ & ND \\
\hline $18: 0$ iso & $1 \cdot 6$ & ND \\
\hline $18: 1$ & ND & $19 \cdot 0$ \\
\hline $\begin{array}{l}18: 1 \omega 7 c \text { or } \omega 9 t \text { or } \\
\quad \omega 12 t\end{array}$ & $18 \cdot 4$ & ND \\
\hline $18: 0$ & $0 \cdot 2$ & $0 \cdot 3$ \\
\hline $\begin{array}{l}\text { Unknown or } 19: 0 \\
\text { cyclo } \omega 10 c\end{array}$ & $0 \cdot 1$ & ND \\
\hline
\end{tabular}

Furthermore, it could not be placed in any of the 40 Vibrio species in the database. The closest fits were to Vibrio cholerae Inaba, Vibrio fluvialis and Vibrio furnissi, but strain $\mathrm{AK} 1^{\mathrm{T}}$ differed from each of them by more than these species differed from one another. A further indication that the cell surface of strain $\mathrm{AK} 1^{\mathrm{T}}$ is very different from that of $V$. mediterrane $i$ was that antibodies prepared against strain $\mathrm{AK} 1^{\mathrm{T}}$ did not react with $V$. mediterranei ATCC $43341^{\mathrm{T}}$. 
Table 2. Phenotypic differences between $V$. shiloi $A K 1^{\top}$ and $V$. mediterranei ATCC $43341^{\top}$

\begin{tabular}{|c|c|c|}
\hline Character & V. shiloi $\mathrm{AK}^{\mathrm{T}}$ & V. mediterranei ATCC $43341^{\mathrm{T}}$ \\
\hline Bleaching of Oculina patagonica* & + & - \\
\hline \multicolumn{3}{|l|}{ Fatty acid content $(\%$ of total $)$ : } \\
\hline $16: 1$ & ND & $30 \cdot 0$ \\
\hline $16: 1 \omega 7 c$ or $15: 0$ iso $2-\mathrm{OH}$ & $32 \cdot 6$ & ND \\
\hline $17: 1$ & ND & $2 \cdot 5$ \\
\hline $18: 1$ & ND & $19 \cdot 0$ \\
\hline $18: 1 \omega 7 c$ or $\omega 9 t$ or $\omega 12 t$ & $18 \cdot 4$ & ND \\
\hline Reaction to anti-Vibrio sp. AK1 antibodies & + & - \\
\hline Growth on $6 \% \mathrm{NaCl}$ & - & + \\
\hline \multicolumn{3}{|l|}{ Utilization of: } \\
\hline$N$-Acetyl D-galactosamine & - & + \\
\hline$m$-Inositol & - & + \\
\hline Monomethyl succinate & - & + \\
\hline$\beta$-Hydroxybutyric acid & + & - \\
\hline Methyl $\beta$-D-glucoside & + & - \\
\hline D-Lactose & + & - \\
\hline L-Rhamnose & + & - \\
\hline Glucuronamide & + & - \\
\hline
\end{tabular}

* Bleaching experiments were conducted by spotting $10^{6}$ bacterial cells on corals and incubating them for 3 weeks in a 21 aerated aquarium at $25^{\circ} \mathrm{C}$.

ND, Not detected.

Biochemical tests and carbon compound utilization data of the two independently isolated coral pathogens $V$. shiloi $\mathrm{AK} 1^{\mathrm{T}}$ and $V$. shiloi $\mathrm{AK} 2$ were identical. For comparative purposes, all of the tests were performed on $V$. mediterranei ATCC $43341^{\mathrm{T}}$ under the same conditions. The phenotypic differences between $V$. shiloi $\mathrm{AK} 1^{\mathrm{T}}$ and $V$. mediterranei are summarized in Table 2.

\section{DISCUSSION}

The causative agent of bleaching of the coral $O$. patagonica (Kushmaro et al., 1996, 1997) is a Vibrio species, based on all genotypic and phenotypic tests performed. The question of whether to classify it as a new species, closely related to $V$. mediterranei, or as a subspecies of $V$. mediterranei is arbitrary. The $16 \mathrm{~S}$ rDNA sequence similarity $(99.4 \%)$ and total DNADNA hybridization data $(72 \%)$ are both borderline values for what would currently be defined as a new species. For example, V. cholerae (classic Ogawa) and Vibrio mimicus show $99.6 \%$ sequence identity in their $16 \mathrm{~S}$ rDNAs and are considered different species. When one takes additional data into consideration (Table 2), it would appear that the definition of a new species is justified. The property that led to the isolation of $V$. shiloi $\mathrm{AK} 1^{\mathrm{T}}$ and $\mathrm{AK} 2$ is its ability to infect and bleach its host coral. This virulence property is not only of considerable ecological significance, but also leads to a unique lifestyle. V. shiloi $\mathrm{AK} 1^{\mathrm{T}}$ adheres specifically to its host coral, penetrates into the coral tissue, multiplies intracellularly and subsequently kills the coral zooxanthellae, leading to coral bleaching (Banin et al., 2000; Ben-Haim et al., 1999). $V$. mediterranei is not a coral pathogen and has never been shown to grow intracellularly.

The large differences in cellular fatty acids between $V$. shiloi $\mathrm{AK} 1^{\mathrm{T}}$ and $V$. mediterranei should be considered as an additional valuable tool in evaluating taxonomic differences between the two strains. The major fatty acids in $V$. mediterranei are hexadecane $(30 \%)$ and octadecane (19\%), both of which are not present in $V$. shiloi $\mathrm{AK} 1^{\mathrm{T}}$. Also, the major fatty acids in $V$. shiloi $\mathrm{AK} 1^{\mathrm{T}}$ are not present in $V$. mediterranei (Table 2). It is also relevant that polyclonal antibodies generated against $V$. shiloi $\mathrm{AK} 1^{\mathrm{T}}$ reacted strongly with $V$. shilo $i$ AK2, but reacted very weakly, if at all, with $V$. mediterranei. It may be that the very different fatty acids and cell-surface antigens reflect a different style of growth. In this regard, we have never been able to isolate $V$. shiloi from seawater, only from bleached corals.

Another significant difference between $V$. shiloi and $V$. mediterrane $i$ is their salt tolerance. All $V$. mediterranei strains grow in the presence of $6 \% \mathrm{NaCl}$, whereas $V$. shiloi $\mathrm{AK} 1^{\mathrm{T}}$ failed to grow in media containing more than $4 \% \mathrm{NaCl}$. Comparison of carbon compound utilization data of $V$. shiloi $\mathrm{AK}^{\mathrm{T}}$ and $V$. mediterranei showed eight differences (Table 2). The ability of $V$. shiloi $\mathrm{AK} 1^{\mathrm{T}}$ to utilize $\beta$-hydroxybutyrate is not common amongst members of the genus Vibrio. The literature indicates that all $V$. mediterranei strains fail to utilize methyl $\beta$-D-glucoside, D-lactose and 
L-rhamnose (Farmer \& Hickman-Brenner, 1992), whereas $V$. shiloi $\mathrm{AK} 1^{\mathrm{T}}$ utilized these compounds.

\section{Description of Vibrio shiloi sp. nov.}

Vibrio shiloi (shi'lo.i. N.L. gen. n. shiloi of Shilo, named after the late microbiologist Moshe Shilo).

Vibrio shiloi conforms to the descriptions of the family Vibrionaceae and of the genus Vibrio (Farmer \& Hickman-Brenner, 1992). Cells are Gram-negative, non-spore-forming rods $(2.4 \times 1.6 \mu \mathrm{m})$ that are motile by a single, polar, sheathed flagellum when grown on solid or liquid medium. Colonies are pale yellow on Marine agar after $48 \mathrm{~h}$ incubation at $30^{\circ} \mathrm{C}$, have slightly serrated edges and do not luminesce. When grown on $0.4 \%$ agar, the cells swarm. Oxidase- and catalase-positive. Produces acid, but not gas, aerobically and anaerobically from D-glucose and sucrose. Growth in Marine broth occurs at $16-37^{\circ} \mathrm{C}$ but not at $42{ }^{\circ} \mathrm{C}$. Grows in Nutrient broth containing 2-4\% $\mathrm{NaCl}$, but no growth in 1 or $6 \% \mathrm{NaCl}$. Reduces nitrate to nitrite and produces indole. Shows positive reactions for lysine decarboxylase, $\beta$-galactosidase, gelatinase and $\beta$-glucosidase and negative reactions for ornithine decarboxylase, urease and arginine dihydrolase. Cells utilize dextrin, glycogen, Tweens 40 and 80, $N$-acetyl D-glucosamine, cellobiose, D-fructose, L-fructose, D-mannitol, D-mannose, methyl $\beta$-D-glucoside, Dpsicose, L-rhamnose, D-sorbitol, D-trehalose, turanose, methyl pyruvate, cis-aconitate, citric acid, D-galactonic acid lactone, D-gluconic acid, D-glucuronic acid, $\beta$ hydroxybutyric acid, DL-lactic acid, succinic acid, bromosuccinic acid, glucuronamide, L-alanine, L-alanyl glycine, L-asparagine, L-aspartic acid, L-glutamic acid, glycyl L-aspartate, glycyl L-glutamate, L-histidine, L-ornithine, L-proline, L-serine, L-threonine, $\gamma$ aminobutyric acid, urocanic acid, inosine, uridine, thymidine, putrescine, glycerol, glucose 1-phosphate and glucose 6-phosphate. Susceptible to 2,4-diamino6,7-diisopropylpteridine (O129 vibriostatic agent), penicillin, ampicillin, tetracycline, oxytetracycline, streptomycin and kanamycin.

Isolated from and pathogenic for the Mediterranean coral Oculina patagonica, causing death of the endosymbiotic zooxanthellae and bleaching of the coral at temperatures of 20 to $32^{\circ} \mathrm{C}$. The type strain is strain $\operatorname{AK}^{\mathrm{T}}\left(=\right.$ ATCC BAA-91 $\left.{ }^{\mathrm{T}}=\mathrm{DSM} 13774^{\mathrm{T}}\right)$.

\section{ACKNOWLEDGEMENTS}

We thank R. Rudner for providing the primers for the $16 \mathrm{~S}$ rDNA PCR. This work was supported by BSF grant 95-00177, the Pasha Gol Chair for Applied Microbiology and the Israel Center for the Study of Emerging Diseases.

\section{REFERENCES}

Banin, E., Israely, T., Kushmaro, A., Loya, Y., Orr, E. \& Rosenberg, E. (2000). Penetration of the coral-bleaching bacterium Vibrio shiloi into Oculina patagonica. Appl Environ Microbiol 66, 3031-3036.

Ben-Haim, Y., Banin, E., Kushmaro, A., Loya, Y. \& Rosenberg, E. (1999). Inhibition of photosynthesis and bleaching of zooxanthellae by the coral pathogen Vibrio shiloi. Environ Microbiol 1, 223-229.

Brown, B. E., Le Tissier, M. D. A. \& Bythell, J. C. (1995). Mechanisms of bleaching deduced from histological studies of reef corals sampled during a natural bleaching event. Mar Biol 122, 655-663.

Cashion, P., Holder-Franklin, M. A., McCully, J. \& Franklin, M. (1977). A rapid method for the base ratio determination of bacterial DNA. Anal Biochem 81, 461-466.

Escara, J. F. \& Hutton, J. R. (1980). Thermal stability and renaturation of DNA in dimethyl sulfoxide solutions: acceleration of the renaturation rate. Biopolymers 19, 1315-1327.

Farmer, J. J., III \& Hickman-Brenner, F. W. (1992). The genera Vibrio and Photobacterium. In The Prokaryotes, 2nd edn, pp. 2952-3011. Edited by A. Balows, H. G. Trüper, M. Dworkin, W. Harder \& K.-H. Schleifer. Heidelberg: Springer.

Glynn, P. W. (1991a). Coral reef bleaching in the 1980s and possible connections with global warming. Trends Ecol Evol 6, 175-179.

Glynn, P. W. (1991b). Elimination of two reef-building hydrocorals following the 1982-83 El-Nino warming event. Science 253, 69-71.

Goreau, T. J. (1990). Coral bleaching in Jamaica. Nature 343, 417.

Goreau, T. J. (1994). Coral bleaching and ocean 'hot spots'. Ambio 23, 176-180.

Hoegh-Guldberg, O. (1999). Climate change, coral bleaching and the future of the world's coral reefs. Mar Freshwater Res 50, 839-866.

Huß, V. A. R., Festl, H. \& Schleifer, K. H. (1983). Studies on the spectrophotometric determination of DNA hybridization from renaturation rates. Syst Appl Microbiol 4, 184-192.

Jahnke, K. D. (1992). Basic computer program for evaluation of spectroscopic DNA renaturation data from Gilford System 2600 spectrophotometer on a PC/XT/AT type personal computer. J Microbiol Methods 15, 61-73.

Jokiel, P. L. \& Coles, S. L. (1990). Response of Hawaiian and other Indo-Pacific reef corals to elevated temperature. Coral Reefs 9, 155-162.

Kita-Tsukamoto, K., Oyaizu, H., Nanba, K. \& Simidu, U. (1993). Phylogenetic relationships of marine bacteria, mainly members of the family Vibrionaceae, determined on the basis of $16 \mathrm{~S}$ rRNA sequences. Int $J$ Syst Bacteriol 43, 8-19.

Kushmaro, A., Loya, Y., Fine, M. \& Rosenberg, E. (1996). Bacterial infection and coral bleaching. Nature 380, 396.

Kushmaro, A., Rosenberg, E., Fine, M. \& Loya, Y. (1997). Bleaching of the coral Oculina patagonica by Vibrio AK-1. Mar Ecol Prog Ser 147, 159-165.

Kushmaro, A., Rosenberg, E., Fine, M., Ben-Haim, Y. \& Loya, Y. (1998). Effect of temperature on bleaching of the coral Oculina patagonica by Vibrio AK-1. Mar Ecol Prog Ser 171, 131-137.

Pujalte, M.-J. \& Garay, E. (1986). Proposal of Vibrio mediterranei sp. nov: a new marine member of the genus Vibrio. Int $J$ Syst Bacteriol 36, 278-281.

Rudner, R., Martsinkevich, O., Leung, W. \& Jarvis, E. D. (1998). Classification and genetic characterization of pattern-forming Bacilli. Mol Microbiol 27, 687-703. 
A. Kushmaro and others

Sambrook, J., Fritsch, E. F. \& Maniatis, T. (1989). Molecular Cloning : a Laboratory Manual, 2nd edn. Cold Spring Harbor, NY: Cold Spring Harbor Laboratory.

Toren, A., Landau, L., Kushmaro, A., Loya, Y. \& Rosenberg, E. (1998). Effect of temperature on adhesion of Vibrio strain AK-
1 to Oculina patagonica and on coral bleaching. Appl Environ Microbiol 64, 1379-1384.

Urdaci, M. C., Marchand, M. \& Grimont, P. A. D. (1990). Characterization of 22 Vibrio species by gas chromatography analysis of their cellular fatty acids. Res Microbiol 141, 437-452. 